\title{
Kelola
}

\section{Peningkatan Kompetensi Guru Dalam Perencanaan Pembelajaran Tematik Melalui Supervisi Kelompok Pendekatan Kolaboratif}

\author{
Rukayah \\ SD Negeri Ungaran 05 \\ rukayah.spd@gmail.com
}

\begin{abstract}
This research was conducted with the aims to improve the competence of developing thematic learning plans in improving the quality of thematic learning in class I, II, and III in primary school Ungaran 05. Subjek research in this action research is a low-grade teacher at SD Negeri Ungaran 05. The school action researcher was conducted in two cycles, with the stages of planning, acting, observing and reflecting in each cycle. The collected data is analyzed quantitatively and qualitatively. The results of school action research concluded that group supervision with collaborative approach can improve the competence of lower class teachers in Elementary School Ungaran 05 in preparing thematic lesson planning.
\end{abstract}

Keywords: collaborative, competence, learning, supervision, thematic

\section{Article Info}




\section{PENDAHULUAN}

Banyak persoalan yang dihadapi dalam proses pendidikan. Kepala sekolah, guru, peserta didik, dan stakeholder lainya hampir dapat dipastikan mempunyai persoalan atau masalah dalam kaitannya dengan pembelajaran. Guru sebagai pemeran utama dalam pembelajaran juga tidak luput dari masalah mengajar, karenanya dibutuhkan pengalaman, masukan, bantuan dan pendapat dari orang lain guna memecahkan atau memberikan alternatif solusi atas persoalan yang dihadapi guru tersebut. Sebagai pemeran utama dalam pembelajaran, guru dituntut untuk berinovasi. Pembelajaran dapat dirumuskan sebagai proses interaksi dalam satu lingkungan belajar tertentu antara guru, peserta didik dan sumber-sumber belajar yang tersedia. Proses pembelajaran itu sendiri meliputi tahap perencanaan, pelaksanaan, dan penilaian. Pada tahap perencanaan, para guru di semua satuan pendidikan wajib menyusun Rencana Pelaksanaan Pembelajaran (RPP) yang lengkap dan sistematis agar pembelajaran dapat berlangsung secara interaktif, inspiratif, menyenangkan, menantang, dan memotivasi seluruh peserta didik berpartisipasi aktif, serta memberikan kesempatan yang memadai prakarsa, kreativitas, dan kemandirian para peserta didik sesuai dengan bakat, minat, dan perkembangan fisik serta psikologis mereka masing-masing.

Peserta didik yang duduk di kelas satu, dua dan tiga Sekolah Dasar hakikatnya masih termasuk dalam rentangan usia dini, yang mengalami perkembangan kecerdasan baik kecerdasan akademik, kecerdasan emosional maupun kecerdasan spiritual yang sangat luar biasa (Tryanasari, Mursidik, \& Riyanto, 2013: 139). Pada tahap perkembangan ini peserta didik memandang semua hal sebagai satu keutuhan dan mereka pun sudah paham relasi antar konsep sederhana berdasarkan pada obyek-obyek yang nyata. Proses pembelajaran peserta didik kelas bawah masih bergantung kepada objek-objek nyata dan hal-hal yang dialami secara langsung. Oleh karena itu pembelajaran di kelas bawah lebih tepat dan akan efektif jika dikelola dengan pendekatan pembelajaran tematik. Oleh karena itu pula lah para guru di kelas bawah perlu menyusun RPP bagi kegiatan pembelajaran tematik, yaitu RPP Tematik. Pembelajaran tematik adalah suatu pendekatan dalam mengintegrasikan kurikulum dan dilaksanakan dalam pembelajaran di sekolah dasar (Nugroho, 2016:82).

Berdasarkan supervisi akademik yang dilakukan Kepala Sekolah pada bulan November 2016, terhadap 3 (tiga) orang guru kelas bawah di SD Negeri Ungaran 05, ternyata ke-tiga orang guru itu, belum menggunakan pendekatan pembelajaran tematik. Baik dalam menyusun RPP maupun melaksanakan pembelajaran di kelas mereka masih menerapkan pola pembelajaran mata pelajaran terpisah. Para guru masih menggunakan pola pembelajaran terpisah karena belum memahami bagaimana mengelola pembelajaran tematik secara efektif dan efisien. Berdasarkan permasalahan itu maka peneliti selaku Kepala Sekolah merasa perlu untuk melaksanakan supervisi terhadap para guru kelas bawah, agar dapat menyusun Rencana Pelaksanaan Pembelajaran Tematik yang baik melalui sebuah PTS (PTS). Harapannya kelak para Guru tersebut dapat pula melaksanakan pembelajaran tematik sesuai acuan Standar Proses pendidikan yang berlaku

Supervisi merupakan usaha petugaspetugas sekolah dalam memimpin guru-guru dan petugas-petugas lainnya dalam memperbaiki pengajaran, termasuk menstimulasi, menyelesaikan pertumbuhan jabatan dan perkembangan guru-guru serta merevisi tujuan-tujuan pendidikan (Cartel dalam Sahertian, 2000: 17). Menurut Prasojo (2011: 3) salah satu tujuan supervisi adalah membantu guru untuk meningkatkan 
Peningkatan Kompetensi Guru Kelas Bawah Dalam Menyusun Perencanaan ... | Rukayah

kompetensinya. Supervisi dilakukan oleh atasan kepada bawahan, dalam hal ini adalah kepala sekolah kepada guru dengan tujuan agar terjadi peningkatan kompetensi (Bahri, 2014: 102). Sementara Yusak dan Darmawan (2017: 50) mengungkapkan bahwa bagi sebuah sekolah, supervisi penting untuk dilakukan agar dapat mengontrol kualitas dan kegiatankegiatan pembelajaran di sekolah. Jadi dengan dilaksanakan supervisi, kompetensi guru diharapkan meningkat dan akhirnya kualitas pembelajaran dapat ditingkatkan.

Terdapat banyak ragam supervisi kepala sekolah terhadap guru, salah satunya adalah supervisi kelompok dengan pendekatan kolaboratif. Tentang Supervisi Kelompok Pendekatan Kolaboratif, Giarti (2015: 40) menjelaskan bahwa secara etimologis kata supervisi berasal dari kata super artinya atas dan visi yang artinya penglihatan. Dari pengertian tersebut Giarti (2015: 40) mendefinisikan supervisi adalah posisi yang melihat atau kedudukan yang lebih tinggi daripada yang dilihat. Sementara Merukh dan Sulasmono (2016: 31) menjelaskan bahwa supervisi pendidikan adalah upaya perbaikan pengajaran sebagai upaya agar terjadinya pertumbuhan jabatan profesional guru. Supervisi kelompok merupakan satu cara melaksanakan supervisi yang ditujukan pada dua atau lebih guru (Pusat Pengembangan Tenaga Kependidikan, 2014: 7).

Menurut Sahertian, (2000:44-52). pendekatan kolaboratif adalah cara pendekatan yang memadukan cara pendekatan direktif dan non-direktif kedalam satu pendekatan baru. Dalam pendekatan ini baik supervisor maupun guru bersama-sama, bersepakat untuk menetapkan struktur, proses dan kriteria dalam melaksanakan proses percakapan terhadap masalah yang dihadapi guru. Pendekatan ini didasarkan pada psikologi kognitif. Psikologi kognitif beranggapan bahwa belajar adalah hasil panduan antara kegiatan individu dengan lingkungan pada gilirannya nanti berpengaruh dalam pembentukan aktivitas individu. Dengan demikian pendekatan dalam supervisi berhubungan pada dua arah yaitu dari atas ke bawah dan dari bawah ke atas. Perilaku supervisor dalam supervisi jenis ini adalah sebagai berikut: menyajikan, menjelaskan, mendengarkan, memecahkan masalah, dan negosiasi. Efektivitas supervisi kelompok berbasis kolaborasi ini antara lain dibuktikan dari penelitian yang dilakukan oleh Jaya, Samsudi, \& Prihatin (2015:158) yang menunjukkan bahwa supervisi berbasis kolaborasi efektif untuk meningkatkan kompetensi profesional guru.

Supervisi yang hendak dilakukan melalui PTS ini adalah supervisi kelompok, sedang pendekatan yang hendak digunakan adalah pendekatan kolaboratif. Tujuan supersisi ini adalah meningkatkan kompetensi guru kelas bawah dalam merencanakan pembelajaran tematik. Rumusan masalah PTS ini adalah "Apakah supervisi kelompok dengan pendekatan kolaboratif dapat meningkatkan kompetensi guru dalam menyusun perencanaan pembelajaran tematik guru kelas bawah SD Negeri Ungaran 05 Kecamatan Ungaran Barat Kabupaten Semarang". Sedang tujuan PTS ini adalah meningkatkan kompetensi guru guru kelas bawah SD Negeri Ungaran 05 Kecamatan Ungaran Barat Kabupaten Semarang dalam menyusun perencanaan pembelajaran tematik. Ada pun hipotesis yang dikemukakan dalam PTS ini adalah "Supervisi kelompok dengan pendekatan kolaboratif dapat meningkatkan kompetensi menyusun perencanaan pembelajaran tematik bagi guru kelas bawah SD Negeri Ungaran 05 Kecamatan Ungaran Barat Kabupaten Semarang"

\section{METODE PENELITIAN}

Penelitian ini termasuk jenis penelitian tindakan namun bukan tindakan kelas melainkan tindakan sekolah. Jadi penelitian ini nukan berbasis kelas melainkan berbasis 
sekolah, walaupun penelitian ini juga melibatkan para guru di sekolah yang diteliti yaitu di SD Negeri Ungaran 05.

Penelitian dilaksanakan selama 3 (tiga) bulan. Siklus I dilakukan selama minggu ke-2 bulan Pebruari 2017 dan Siklus II dilakukan pada minggu ke-empat bulan Pebruari 2017. PTS ini dilakukan di SD Negeri Ungaran 05 Kecamatan Ungaran Barat Kabupaten Semarang. Subjek penelitian ini adalah para guru kelas bawah (guru kelas I, II, dan guru kelas III) SD Negeri Ungaran 05 Kecamatan Ungaran Barat Kabupaten Semarang.

Teknik pengumpulan data adalah teknik observasi untuk menilai proses supervisi dan studi dokumen untuk menilai kualitas RPP. Instrumen yang digunakan dalam penelitian ini adalah lembar observasi kegiatan supervisi dalam buku Supervisi Implementasi Kurikulum 2013, Bahan Ajar Implementasi Kurikulum 2013 Untuk Kepala Sekolah. Instrumen ini digunakan oleh pengawas SD UPTD Kecamatan Ungaran Barat untuk memantau proses pelaksanaan tindakan oleh Kepala Sekolah. Data tentang skor RPP para guru sebelum tindakan, dan skor RPP yang diperoleh para guru setelah mendapatkan tindakan melalui siklus I dan siklus II diperoleh dengan menggunakan Iinstrument monitoring dan evaluasi.

Penelitian ini menggunakan teknik teknik kuantitatif dan teknik kualitatif dalam menganalisis data. Teknik kuantitatif digunakan untuk menganalisis skor evaluasi kualitas RPP tematik yang disusun para Guru baik pada tahap pra siklus, siklus I maupun siklus II. Skor dihitung dengan cara: (1) memberi skor tiap aspek yang diperoleh Guru dalam rentang 1-5; dan (2) menghitung jumlah skor kumulatif dari seluruh aspek RPP yang disusun Guru. Kategori tingkat keberhasilan para Guru adalah sebagai berikut.
Tabel 1. Kategori Tingkat Keberhasilan

\begin{tabular}{cl}
\hline Skor & \multicolumn{1}{c}{ Kategori } \\
\hline $1-7$ & Sangat tidak baik \\
\hline $8-14$ & Tidak baik \\
\hline $15-21$ & Kurang baik \\
\hline $22-27$ & Baik \\
\hline $28-35$ & Sangat baik \\
\hline
\end{tabular}

Data hasil observasi dianalisis dngan teknik kualitatif dan dilakukan pada proses refleksi di akhir setiap siklus. Data kualitatif diperoleh dari observer yang melakukan observasi pada kegiatan tindakan. Data yang terkumpul kemudian dipilah dan ditemukan permasalahan yang perlu ditingkatkan sehingga tujuan tindakan dapat tercapai, dengan demikian dapat melakukan perbaikan pada siklus kedua.

Langkah-langkah pokok dalam PTS ini meliputi: 1) Menetapkan fokus masalah; 2) Merencanakan tindakan; 3) Melaksanakan tindakan; 4) Mengumpulkan data (pengamatan); 5) Refleksi, analisis, dan interpretasi; 6) Merencanakan tindak lanjut.: Tahap menetapkan fokus masalah dimulai dengan tindakan merenungkan atau memikirkan hasil supervisi awal sebelum siklus I. Tahap merencakan tindakan dilakukan sebagai upaya mempersiapkan langkah pemecahan masalah-masalah yang ditemukan dalam refleksi awal. Melalui perencanaan ini maka diharapkan tindakan supervisi akan lebih sistematis dan terarah. Langkah-langkah perencanaan proses supervisi ini mencakup: (a) menyusun rencana supervisi terhadap Guru dalam menyusun RPP tematik, dan (b) menyusun instrumen monitoring dan evaluasi terhadap RPP.

Tahap Pelaksanaan Tindakan berupa kegiatan supervisi kelompok dengan pendekatan kolaboratif dilakukan sesuai dengan rencana yang telah disusun yaitu mensupervisi guru secara kelompok dalam merencanakan pembelajaran tematik. Walaupun supervise dilakukan secara kelompok namun RPP harus disusun oleh guru 
Peningkatan Kompetensi Guru Kelas Bawah Dalam Menyusun Perencanaan ... | Rukayah

secara individu. Langkah pengamatan dilakukan terhadap proses supervisi akademik yang dilakukan peneliti. Pada tahap refleksi. peneliti bersama guru mendiskusikan kelebihan dan kelemahan pelaksanaan tindakan dalam siklus I dan siklus II, baik dari perencanaan, tindakan, dan pengamatan. Dalam tahap Rencana tindak lanjut, segala kekurangan yang terjadi selama pelaksanaan siklus I difungsikan sebagai bahan evaluasi dan dasar perencanaan tindakan pada siklus II.

Indikator keberhasilan dalam PTS ini adalah jika semua guru kelas bawah SD Negeri Ungaran 05 Kecamatan Ungaran Barat Kabupaten Semarang, memperoleh skor kumulatif minimal 22 atau sudah masuk ke dalam kategori Baik.
HASIL PENELITIAN DAN

PEMBAHASAN.

Hasil Penelitian

Hasil Refleksi Awal

Kondisi awal merupakan kondisi sebelum tindakan dilakukan dalam siklus I. Sebagai supervisor, peneliti melakukan supervisi akademik kunjungan kelas, terutama untuk memonitor dan meng-evaluasi dokumen rencana pembelajaran yang disusun para guru kelas bawah.

Supervisi awal menunjukkan bahwa para guru kelas bawah belum melaksanakan pembelajaran tematik. Guru -guru kelas awal masih menerapkan pembelajaran secara terpisah. Mereka belum mampu mengelola pembelajaran tematik, sementara Kepala Sekolah juga belum pernah melakukan supervisi tentang penyusunan RPP tematik.

Secara ringkas data tentang kompetensi guru kelas bawah dalam merencanakan pembelajaran tematik di kelasnya adalah sebagai berikut.

Tabel 2. Hasil Supervisi Akademik tarhadap Guru Kelas Bawah

\begin{tabular}{|c|c|c|c|c|c|c|c|c|c|c|}
\hline \multirow{3}{*}{ No } & \multirow{3}{*}{ Guru Kelas } & \multicolumn{9}{|c|}{ Jenis Administrasi } \\
\hline & & \multicolumn{3}{|c|}{ Silabus } & \multicolumn{3}{|c|}{ Promes } & \multicolumn{3}{|c|}{ RPP } \\
\hline & & 1 & 2 & 3 & 1 & 2 & 3 & 1 & 2 & 3 \\
\hline 1 & I & & $\mathrm{V}$ & & & $\mathrm{V}$ & & $\mathrm{V}$ & & \\
\hline 2 & II & & $\mathrm{V}$ & & & $\mathrm{V}$ & & $\mathrm{V}$ & & \\
\hline 3 & III & & V & & & V & & V & & \\
\hline & $\begin{array}{l}\text { rangan: } \\
\text { Produk orang } \\
\text { Produk hasil } \\
\text { Produk sendir }\end{array}$ & & & & & & & & & \\
\hline
\end{tabular}

Tabel 2 di atas menunjukkan bahwa pada awal semester II tahun pelajaran 2016/2017 para guru kelas bawah di SD Negeri Ungaran 05 Kecamatan Ungaran Barat, menggunakan perangkat-perangkat rencana pembelajaran baik silabus maupun program semesteran hasil KKG, sementara untuk RPP para Guru menggunakan RPP karya orang lain. Para guru belum menerapkan pembelajaran tematik di kelas masing-masing, sehingga RPP yang ada hanya berfungsi terbatas sebagai dokumen semata.

Data kompetensi guru kelas bawah dalam merencanakan pembelajaran tematik adalah sebagai berikut.

Tabel 3. Hasil Monitoring Dan Evaluasi Terhadap RPP

Sebelum Tindakan

\begin{tabular}{cccl}
\hline No & Guru Kelas & Perolehan Skor & Kategori \\
\hline 1 & I & 13 & Tidak Baik \\
\hline 2 & II & 15 & Kurang Baik \\
\hline 3 & III & 13 & Tidak Baik
\end{tabular}

Sumber: Data Penelitian 


\section{Hasil Tindakan Siklus I}

Dalam Siklus I peneliti -yang berstatus sebagai Kepala Sekolah di SD tempat penelitian-, melakukan tindakan dengan membantu penyelesaian masalah-masalah guru dalam merencanakan pembelajaran tematik. Secara bersama-sama diidentifikasi kesulitan para guru dalam merencakan pembelajaran tematik. Berdasarkan temuan itu, peneliti kemudian memberikan solusi terhadap kesulitan yang dihadapi para guru.
Para guru diberi petunjuk-petunjuk yang operasional dan mudah untuk dilaksanakan, serta didampingi dalam menyusun RPP tematik.

Hasil tindakan berupa supervisi akademik dengan pendekatan kolaboratif terhadap guru kelas bawah di dalam merencanakan pembelajaran tematik pada Siklus I adalah sebagai berikut:

Tabel 4. Hasil Monitoring dan Evaluasi Terhadap RPP Pada Tindakan

Siklus I

\begin{tabular}{lcccccc}
\hline \multirow{2}{*}{ No } & Guru & \multicolumn{5}{c}{ Perolehan Skor } \\
\cline { 3 - 6 } & Kelas & \multicolumn{2}{c}{ Sebelum tindakan } & \multicolumn{2}{c}{ Siklus I } & \multirow{2}{*}{ Peningkatan } \\
\cline { 3 - 6 } & Skor & Kategori & Skor & Kategori & \\
\hline 1 & I & 13 & TB & 18 & KB & 5 skor \\
\hline 2 & II & 16 & KB & 24 & B & 8 skor \\
\hline 3 & III & 13 & TB & 20 & KB & 7 skor \\
\hline
\end{tabular}

Sumber: Data penelitian

Tabel 4 di atas menunjukkan bahwa setelah mendapat tindakan supervisi dari peneliti maka terjadi perubahan kompetensi Guru dalam menyusun RPP Tematis. Guru Kelas I, meningkat perolehan skornya sebanyak 5 skor yaitu dari 13 menjadi 18, yang berarti meningkat dari kategori Tidak Baik menjadi Kurang Baik. Jadi terdapat peningkatan kemampuan guru kelas I dalam merencanakan pembelajaran tematik. Guru Kelas II, meningkat perolehan skornya sebanyak 8 skor yaitu dari 16 menjadi 24, yang berarti meningkat dari kategori Kurang Baik menjadi Baik. Jadi terdapat peningkatan kemampuan guru kelas II dalam merencanakan pembelajaran tematik. Guru Kelas III meningkat perolehan sokrnya sebanyak 7 skor yaitu dari 13 menjadi 20, yang berarti meningkat dari kategori Tidak Baik menjadi Kurang Baik. Jadi terdapat peningkatan kemampuan guru kelas III dalam merencanakan pembelajaran tematik.
Berdasarkan hasil observasi masih terdapat kekurangan pada penjelasan tentang ragam metode pembelajaran yang dapat dipilih. Hal tersebut tampak pula dalam hasil RPP yang menunjukkan bahwa guru masih kesulitan untuk memilih ragam metode pembelajaran, khususnya metode pembelajaran yang inovatif. Penjelasan awal pada siklus pertama tentang pemilihan media pembelajaran juga masih perlu diperjelas. Dari dua permasalahan yang ditemukan dalam siklus pertama, maka pada tidakan supervisi siklus kedua perlu memberikan perhatian yang lebih banyak pada dua hal tersebut.

\section{Hasil Tindakan Pada Siklus II}

Tindakan melalui Siklus II tetap dilakukan karena indikator keberhasilan PTS ini belum sepenuhnya tercapai. Memang ada satu Guru yang kemmpaun menyusun RPP Tematisnya sudah mencapai kategori Baik namun perolehan skornya belum maskimal. Pada siklus II, supervisi dilakukan dengan membantu guru mengidentifikasi kekurangan- 
Peningkatan Kompetensi Guru Kelas Bawah Dalam Menyusun Perencanaan ... | Rukayah

kekurangan dari RPP tematik yang telah disusun pada siklus I. Karena kekurangan umumnya lebih pada pemilihan meode dan media pembelajaran yang tepat dan bervariasi makan para guru diberi arahan-arahan yang lebih operasional dan mudah dilaksanakan oleh guru tentang ke dua hal tersebut.
Hasil tindakan berupa supervisi akademik dengan pendekatan kolaboratif terhadap guru kelas bawah di dalam merencanakan pembelajaran tematik pada Siklus II adalah sebagai berikut.

Tabel 5. Hasil monitoring dan evaluasi terhadap RPP pada tindakan siklus II

\begin{tabular}{ccccccc}
\hline & & \multicolumn{5}{c}{ Perolehan Skor } \\
\cline { 3 - 6 } No & Guru & \multicolumn{4}{c}{ Kelas } & \multicolumn{2}{c}{ Siklus I } & \multicolumn{2}{c}{ Siklus II } & Peningkatan \\
\cline { 3 - 5 } & & Skor & Kategori & Skor & Kategori & \\
\hline 1 & I & 18 & KB & 22 & B & 4 skor \\
\hline 2 & II & 24 & B & 27 & B & 3 Skor \\
\hline 3 & III & 20 & KB & 24 & B & 4 skor \\
\hline
\end{tabular}

Sumber: Data penelitian

Tabel di atas menunjukkan bahwa supersisi kelompok dengan pendekatan kolaboratif pada siklus II telah menghasilkan perubahan-perubahan: (1) Skor Guru Kelas I naik 4 skor dari kategori Kurang Baik (skor 18) meningkat menjadi kategori Baik dengan skor 22. Jadi terdapat peningkatan kompetensi guru kelas I dalam merencanakan pembelajaran tematik; (2) Skor Guru Kelas II naik 3 skor dari kategori Baik (skor 24), meningkat menjadi kategori Baik (skor 27). Jadi ada peningkatan kompetensi guru kelas II dalam merencanakan pembelajaran tematik; (3) Skor Guru Kelas III naik 4 skor dari kategori Kurang Baik dengan perolehan skor 20 meningkat menjadi kategori Baik dengan skor 24. Jadi terdapat peningkatan kompetensi guru kelas III dalam merencanakan pembelajaran tematik.

Secara keseluruhan peningkatan kompetensi guru kelas bawah SD Negeri Ungaran 05 Kecamatan Ungaran Barat Kabupaten Semarang dalam merencanakan pembelajaran Tematik dari sejak kondisi awal, siklus I, dan siklus II tergambar dalam tabel berikut ini.

Tabel 6. Hasil Monitoring dan Evaluasi RPP Sebelum Tindakan, Siklus I, dan Siklus II

\begin{tabular}{cccccccc}
\hline & \multicolumn{6}{c}{ Perolehan Skor } \\
\cline { 3 - 8 } No & $\begin{array}{c}\text { Guru } \\
\text { Kelas }\end{array}$ & $\begin{array}{l}\text { Sebelum } \\
\text { tindakan }\end{array}$ & \multicolumn{2}{c}{ Siklus I } & \multicolumn{2}{c}{ Siklus II } \\
\cline { 3 - 8 } & & Skor & Kategori & Skor & Kategori & Skor & Kategori \\
\hline 1 & I & 13 & TB & 18 & KB & 22 & B \\
\hline 2 & II & 16 & KB & 24 & B & 27 & B \\
\hline 3 & III & 13 & TB & 20 & KB & 24 & B \\
\hline \multicolumn{2}{l}{$S 4$}
\end{tabular}

Tabel di atas menunjukkan bahwa terjadi peningkatan kompetensi guru Kelas bawah SD Negeri Ungaran 05 Kecamatan Ungaran Barat dalam merencanakan pembelajaran tematik mulai pra siklus, siklus I, sampai siklus II. Rincian peningkatan itu adalah sebagai berikut. 
(1) Skor Guru Kelas I, meningkat 9 skor, dari kategori Tidak Baik (skor 13) menjadi kategori Baik. (skor 22). Dengan perkataan lain terdapat peningkatan kemampuan guru kelas I dalam merencanakan pembelajaran tematik.

(2) Skor Guru Kelas II, meningkat 11 skor, dari kategori Kurang Baik (skor 16) menjadi kategori Baik. (skor 27). Dengan perkataan lain terdapat peningkatan kemampuan guru kelas II dalam merencanakan pembelajaran tematik..

(3) Skor Guru Kelas III, meningkat 11 skor, dari kategori Tidak Baik (skor 13) menjadi kategori Baik. (skor 24). Dengan perkataan lain terdapat peningkatan kemampuan guru kelas III dalam merencanakan pembelajaran tematik.

\section{Pembahasan}

Hasil penelitian menunjukkan bahwa telah terjadi peningkatan kompetensi guru kelas bawah SD Negeri Ungaran 05 Kecamatan Ungaran Barat dalam merencanakan pembelajaran tematik dari pra siklus, siklus I sampai siklus II melalui supervisi kelompok dengan pendekatan kolaboratif. Hasil tersebut sejalan dengan yang dikemukakan oleh Rosilawati (2014: 59) bahwa pelaksanaan supervisi akademik dapat mengembangkan kemampuan guru dalam merencanakan dan mengelola proses pembelajaran. Prasojo (2011: 13) juga menjelaskan bahwa tujuan supervisi adalah untuk mengembangkan profesionalitas guru dalam perencanaan pembelajaran melalui kegiatan-kegiatan reflektif. Dengan dilaksanakannya supervisi kelompok dengan pendekatan kolaboratif sebagai kegiatan reflektif maka dapat terjadilah peningkatan kompetensi guru sebagaimana ditunjukkan dalam hasil penelitian di atas. Tindakan yang dilakukan dalam penelitian, yang telah menyebabkan terjadinya peningkatan kompetensi guru ini sejalan dengan pandangan Syarif (2011: 112) bahwa dengan dilaksanakannya supervisi kepala sekolah terhadap guru sebagai bentuk tindakan, maka dapat terjadi peningkatan kompetensi guru. Hasil di atas juga sejalan dengan pendapat Darmawan (2014: 31) yang menyatakan bahwa Guru dapat ditingkatkan kompetensinya melalui supervisi akademik karena dalam supervisi terjadi peningkatan pengertian teori dan penerapan pengetahuan

Hasil penelitian ini juga sejalan dengan penelitian yang dilakukan oleh Argiani dan Slameto (2015) yang menunjukkan bahwa pelaksanaan supervisi dapat meningkatkan kompetensi pedagogik guru. Perbedaan tindakan dalam penelitian ini dengan penelitian Argiani dan Slameto (2015) adalah bentuk tindakan yang dilakukan Kepala Sekolah. Tindakan yang gunakan dalam penelitian ini adalah supervisi kelompok, sementara penelitian Argiani dan Slameto (2015) adalah supervisi kunjungan kelas. Selain itu, penelitian ini juga sejalan dengan penelitian Astuti (2017: 58) yang menemukan bahwa dengan dilaksanakannya supervisi akademik maka dapat terjadi peningkatan kemampuan guru. Melalui pelaksanaan supervisi, kepala sekolah dapat melakukan bimbingan dan pengarahan sehingga terjadi peningkatan kompetensi guru yang pada akhirnya berdampak pada peningkatan kinerja guru dan proses pembelajaran. Sujoko (2017: 95) mengungkapkan bahwa salah satu cara untuk meningkatkan mutu sebuah sekolah adalah pelaksanaan supervisi, melalui supervisi guru dapat dibimbing dan diarahkan sehingga terjadi peningkatan kompetensi yang akhirnya dapat meningkatkan mutu sebuah sekolah. Pendapat Sujoko (2017) relevan dengan penelitian ini, yang mana penelitian ini dilaksanakan agar terjadi peningkatan kompetensi guru melalui supervisi.

\section{SIMPULAN DAN SARAN Simpulan}

Paparan hasil tindakan di atas menunjukkan bahwa terjadi peningkatan 
Peningkatan Kompetensi Guru Kelas Bawah Dalam Menyusun Perencanaan ... | Rukayah

kompetensi guru kelas bawah SD Negeri Ungaran 05 Kecamatan Ungaran Barat Kabupaten Semarang. dalam merencanakan pembelajaran tematik sebagai dampak dari dilaksanakannya supervisi kelompok dengan pendekatan kolaboratif.

\section{Saran}

Sesuai dengan paran hasil dan simpulan di atas makan kepada Kepala Sekolah disrankan agar 1) melaksanakan supervisi kelompok dengan pendekatan kolaboratif terhadap guru kelas bawah guna meningkatkan kompetensi Guru dalam merencanakan pembelajaran tematik, dan 2) mengarahkan guru agar selalu mempersiapkan rencana pembelajaran dengan baik, agar efektifitas dan efisiensi pembelajaran dapat terjamin.

\section{DAFTAR PUSTAKA}

Argiani, A.R. dan Slameto. 2015. Supervisi Kunjungan Kelas Untuk Meningkatkan Kompetensi Pedagogik Guru SDN Cukil 01, Tengaran, Kabupaten Semarang. Kelola: Jurnal Manajemen Pendidikan, 2 (1): 1-11.

Astuti, S. 2017. Supervisi Akademik untuk Meningkatkan Kompetensi Guru di SD LaboratoriumUKSW. Scholaria, 7(1): $49-59$.

Bahri, Saiful. 2014. Supervisi Akademik Dalam Peningkatan Profesionalisme Guru. Jurnal Visipena, V (1): 100-112.

Darmawan, I P.A. 2014. Menjadi Guru Yang Terampil. Bandung: Kalam Hidup.

Darmawan, I P.A. 2017. Faktor Yang Mempengaruhi Profesionalitas Guru. Prosiding Seminar Nasional PAK II Dan Call For Papers, Tema: Profesionalisme dan Revolusi Mental Pendidik Kristen. Sekolah Tinggi Teologi Simpson.

Degeng, I N.S. \& Darmawan, I P.A. 2017. Peningkatan Profesionalisme Pendidik
Melalui Penelitian Dan Penulisan Karya Ilmiah. Prosiding Seminar Nasional PAK II Dan Call For Papers, Tema: Profesionalisme dan Revolusi Mental Pendidik Kristen. Sekolah Tinggi Teologi Simpson.

Giarti, S. 2015. Peningkatan Kompetensi Pedagogik Guru SD melalui Supervisi Akademik. Scholaria, 5 (3): 37 - 46.

Jaya, S., Samsudi, \& Prihatin, T. 2015. Supervisi Akademik Kolaborasi Untuk Meningkatkan Kompetensi Profesional Guru Produktif Sekolah Menengah Kejuruan. Educational Management, 4 (2): 158-167.

Merukh, N.E.M. \& Sulasmono, B.S. 2016. Pengembangan Model Supervisi Akademik Teknik Mentoring Bagi Pembinaan Kompetensi Pedagogik Guru Kelas. Kelola: Jurnal Manajemen Pendidikan, 3 (1): 30-48.

Nugroho, I.A. 2016. Pendekatan Ilmiah Dalam Pembelajaran Lintas Kurikulum Di Sekolah Dasar. Yogyakarta: Ikhlasul Workshop.

Peraturan Pemerintah nomor 19 Tahun 2005Tentang Standar Nasional Pendidikan.

Permendiknas nomor 14 Tahun 2007 Tentang Standar Isi Untuk Program Paket A, Program Paket B, dan Program Paket C.

Prasojo, L.D. 2011. Supervisi Pendidikan. Yogyakarta: Gava Media.

Pusat Pengembangan Tenaga Kependidikan. 2014. Supervisi Implementasi Kurikulum 2013, Bahan Ajan Implementasi Kurikulum 2013 Untuk Kepala Sekolah. Jakarta: Pusat Pengembangan Tenaga Kependidikan.

Rosilawati, T. 2014. Supervisi Akademik Dalam Upaya Peningkatan Motivasi 
Kelola: Jurnal Manajemen Pendidikan, Vol. 5, No. 1, Januari-Juni 2018

Guru Menyusun Perangkat Persiapan

Pembelajaran. Jurnal Penelitian

Tindakan Sekolah dan Kepengawasan, 1 (2): 57-62.

Sahertian, Piet. 2000. Konsep Dasar dan Teknik Supervisi Pendidikan dalam rangka Pengembangan Sumberdaya Manusia. Jakarta: Rineka Cipta.

Saptaningrum, E. \& Kusdaryani, W. 2010. Model Pakem Melalui Pendekatan Tematik Untuk Pembelajaran Sains SD. Jurnal Penelitian Pembelajaran Fisika, 1 (1):92-104.

Sujoko, E. 2017. Strategi Peningkatan Mutu Sekolah Berdasarkan Analisis SWOT di Sekolah Menengah Pertama. Kelola: Jurnal Manajemen Pendidikan, 4 (1): 83-96.

Syarif, H.M. 2011. Pengaruh Komunikasi Interpersonal dan Supervisi Kepala Sekolah terhadap Kinerja Guru. Media Akademika, 26 (1): 125-137.

Tryanasari, D., Mursidik, E.M., \& Riyanto, E. 2013. Pengembangan Perangkat Pembelajaran Terpadu Berbasis Kearifan Lokal Untuk Kelas III Sekolah Dasar Di Kabupaten Madiun. Premiere Educandum: Jurnal Pendidikan Dasar dan Pembelajaran. 3 (2): 132-172.

Yusak, L. \& Darmawan, I P.A. 2017. Supervisi Kepala Sekolah Di SD Negeri Kalongan 02, Desa Kalongan, Kecamatan Ungaran Timur. Prosiding Seminar Nasional PAK II dan Call For Papers, Tema: Profesionalisme dan Revolusi Mental Pendidik Kristen. Sekolah Tinggi Teologi Simpson. 